\title{
Lewinskya acuminata (Orthotrichaceae, Bryopsida), a new species for the bryoflora of the Czech Republic
}

Frank Müller

Lewinskya acuminata (Orthotrichaceae, Bryopsida), a new species for the bryoflora of the Czech Republic. - Acta Mus. Siles. Sci. Natur., 68: 189-193, 2019.

\begin{abstract}
Lewinskya acuminata is reported as new for the bryoflora of the Czech Republic. The species was discovered in the Protected Landscape Area "Elbe Sandstone Mountains" (CHKO Labské píscovce) in NW Bohemia. The locality is described in detail. The species is illustrated by photographs. Its diagnostic characters are briefly discussed.
\end{abstract}

Key words: mosses, bryoflora, Orthotrichaceae, epiphytes, Bohemian Switzerland, Elbe Sandstone Mountains

\section{Introduction}

During a bryofloristic survey in the Protected Landscape Area "Elbe Sandstone Mountains" (CHKO Labské píscovce) in NW Bohemia a noteworthy moss of the family Orthotrichaceae was recorded. In the field the cushion of the species looks similar to Lewinskya striata (Hedw.) F.Lara, Garilleti \& Goffinet (=Orthotrichum striatum Hedw.), but was distinguished by very long perichaetial leaves and fusiform capsules of bronzed to rich brown coloration with a reduced exostome. The specimen was identified upon microscopic examination as Lewinskya acuminata (H.Philib.) F.Lara, Garilleti \& Goffinet (=Orthotrichum acuminatum H.Philib.). This discovery turned out to be the first record of the taxa in the Czech Republic.

\section{Description of the species}

Lewinskya acuminata belongs to the phaneroporous and monoicous taxa of Orthotrichum s. 1., which are now treated in the separate genus Lewinskya F.Lara, Garilleti \& Goffinet (Lara et al. 2016). The species looks similar to Lewinskya striata, but is easily recognized by its characteristic fusiform capsules with a reduced peristome and its long-acuminate perichaetial leaves. It is one of the most easily recognized species of Orthotrichum s. 1. in the field (Blockeel 2009).

The diagnostic characters of L. acuminata can be summarized as follows (Ahrens 2004, Blockeel 2009, Van der Pluijm 2001, Lara et al. 2009): Leaves long lanceolate, upper leaves with the apex acuminate and often with elongate apical cells in the apex. Capsules immersed or scarcely emergent, fusiform, when dry narrowly ovoid to subcylindric, almost smooth or often the mouth sulcate in the upper part by 8 short but well marked ribs, capsules somewhat contracted at (but not below) the mouth, mature capsules typically develop a distinctive bronzed or rich brown coloration. Stomata phaneropore. Peristome formed by remains of exostome teeth or only by endostome segments; exostome rudimentary, often appearing absent, each tooth consisting of no more than a plate of 1-3 papillose cells; endostome segments 8, broad, 1-2 cells wide, with irregular margins, opaque, white, incurved and closing the capsule mouth when dry, erect when moist, thick and papillose on both sides. Calyptra with several to many smooth hairs.

Distribution: The species was described as Orthotrichum acuminatum by Philibert (1881) from specimens collected in the Ardeche region of France and the Province of Trento in 
Northern Italy. The species has been found to be widespread and locally frequent in most of the countries bordering the Mediterranean Sea including parts of North Africa and Macaronesia (Hodgetts 2015, Vigalondo et al. 2016). Vigalondo et al. (2016) reported it newly from western North America (California) and eastern Africa (Ethiopia), therefore the distribution comprising the western Nearctic, the western Palaearctic and Palaeotropic.

In European countries northwards of the Mediterranean Basin the species was first recorded in 1992 in the Netherlands (Van der Pluijm 2001). Later it was recorded in 2003 in Germany (Ahrens 2004), in 2004 from Great Britain (Blockeel 2009) and in 2013-2014 from Ticino in Switzerland (Ellis et al. 2014). Most of these extra-Mediterranean finds of L. acuminata are meagre populations and could represent cases of transient populations (Van der Pluijm 2001, Blockeel 2009), but in the Netherlands the species is now known from 28 records and seems to be fully established (BLWG 2019). In Germany beside the first record in the northern Black Forest (Ahrens 2004), the species was found twice, in the forest Hainich in Thuringia (Eckstein 2016) and in the Ore Mountains in Saxony (Müller et al. 2016). The last mentioned record is only about $15 \mathrm{~km}$ away from the German-Czech border, and therefore an occurrence in Czech Republic was expected.

\section{Description of the new locality of Lewinskya acuminata in the Czech Republic}

Protected Landscape Area “Elbe Sandstone Mountains” (CHKO Labské pískovce), Jetřichovice, $150 \mathrm{~m}$ W of the entrance of the PR Pavlínino údolí along the red hiking trail at an old house NW of Grieselův rybník, tree bark of Fraxinus excelsior, 235 m NN, 5050'40.900"N, 14²3'57.141"E, 17 July 2019, leg. Frank Müller (DR\#54800). Associated bryophytes: Lewinskya affinis (Brid.) F.Lara, Garilleti \& Goffinet, Hypnum cupressiforme Hedw., Orthotrichum pallens Bruch ex Brid., Dicranoweisia cirrata (Hedw.) Lindb. ex Milde, Ulota bruchii Hornsch. ex Brid., and Pylaisia polyantha (Hedw.) Schimp.

Lewinskya acuminata was found growing on bark of an ash-tree about $1.5 \mathrm{~m}$ high from ground level at the west-exposed side (Fig. 1). At this tree it is present in one vigorously developed cushion of c. $3 \mathrm{~cm}$ in diameter. In this cushion 11 sporophytes were observed, most of them were already without operculum, but in two sporophytes the operculum still was present. All sporophytes already lacked calyptrae and therefore the features of the calyptrae could not be examined. A second cushion on this tree could also belong to the species. It has the long acuminate leaves as typical for the species, but being in a sterile condition its placement is uncertain. The diagnostic features of the material are illustrated by photographs in Fig. 2 .

\section{Discussion}

The area of the Elbe Sandstone Mountains belonged to a heavily polluted area in the past. It was situated in the so-called "black triangle", affected by emissions of $\mathrm{SO}_{2}$ from industrial areas in Bohemia, Germany and Poland. Due to acid rains, the epiphytic flora of lichens and bryophytes in the region was almost extirpated. In the author's experience it was very difficult to find any epiphytic species of Orthotrichum s. 1. in this area in the 1980s. However, after the political changes in the $1990 \mathrm{~s}$, the emissions of $\mathrm{SO}_{2}$ rapidly decreased. Now a rather rich epiphytic flora occurs. The spread of the epiphytes appears to be associated with both climate changes and improvements of air quality. Among climate elements, for the spread of such a Mediterranean element like L. acuminata the effects of mild winter temperatures may be considered significant.

As the new occurrence of Lewinskya acuminata is very small, both in terms of size of the inhabited area and population size, it is proposed to place the species in the Red List of the Czech Republic in the category CR (critically endangered). 


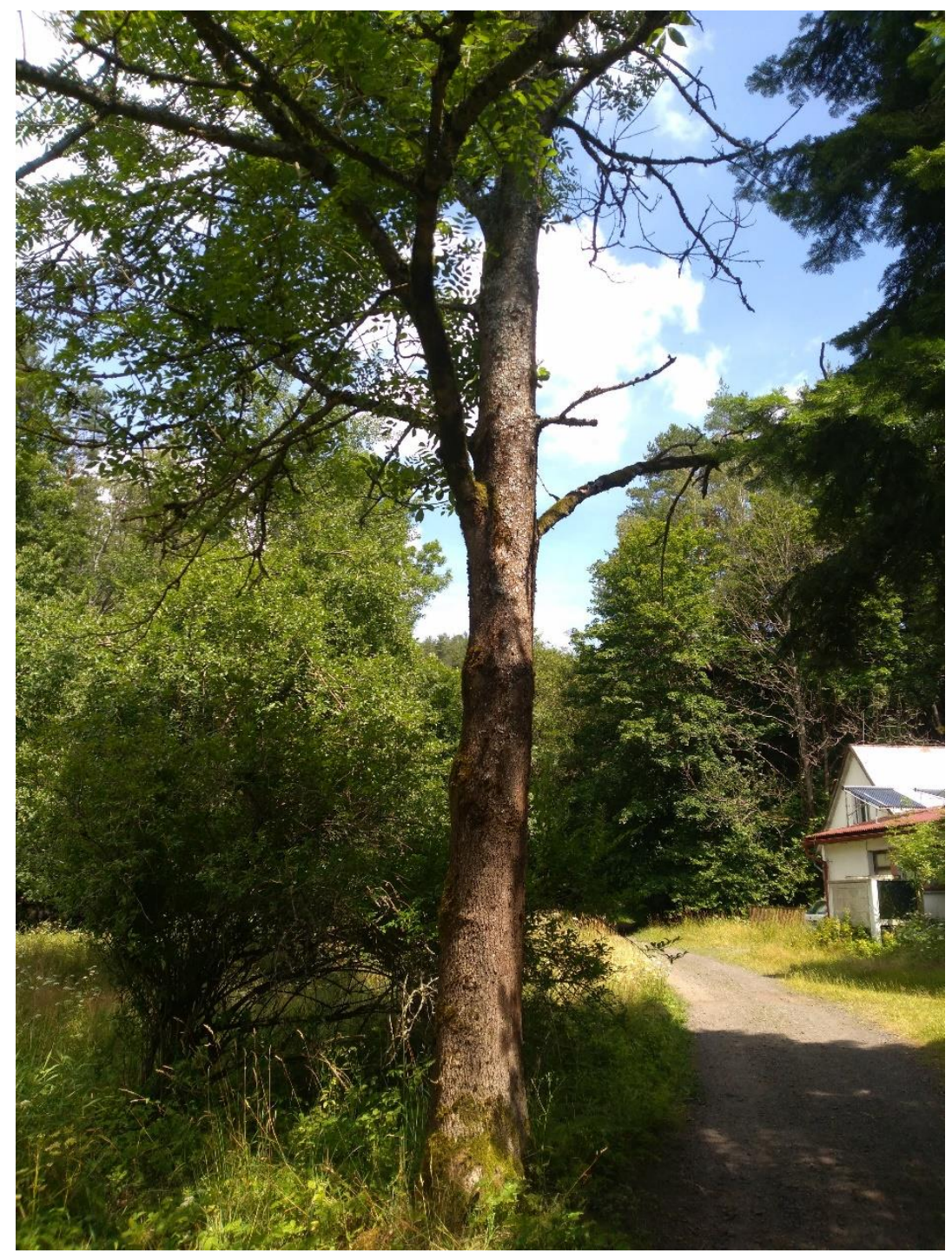

Fig 1: The ash-tree bark where Lewinskya acuminata was found, west of the entrance of the PR Pavlínino údolí near of Jetřichovice, Protected Landscape Area "Elbe Sandstone Mountains” (CHKO Labské pískovce).

Beside Lewinskya acuminata, in the last three decades several epiphytic bryophyte species were recorded as new for the Czech Republic influenced by improving the air quality and/or global warming. The oceanic species Orthotrichum pulchellum Brunt. was first recorded in 2006-2007 at three sites in the České Švýcarsko National Park, the Lužické hory Protected Landscape Area and the Děćínsko region (Plášek \& Marková 2007) and was subsequently found at many additional sites in the Czech Republic (Marková \& Plášek 2013). Further examples of newly recorded species are Ulota macrospora Baur \& Warnst., a species first recorded in Czech Republic in 2013 in the central part of Krušné hory Mountains (Biedermann et al. 2014), and Zygodon dentatus (Limpr.) Breidl. ex Gams, firstly recorded past 1990 in the southern and south-western part of Bohemia, and in 2012 at one site in Bohemian Switzerland National Park in NW Bohemia (Marková \& Plášek 2012).

There are some epiphytic bryophyte species known from the neighboring federal state Saxony of Germany, but remain unknown in the Czech Republic. This group of species includes Lewinskya shawii (Wilson) F.Lara, Garilleti \& Goffinet (Seifert \& Müller 2017), Cryphaea heteromalla (Hedw.) Brid. (Seifert 2009a \& 2009b), Metzgeria consanguinea Schiffn. (Müller et al. 2019), Ulota phyllantha Brid. (Biedermann et al. 2014), Ulota rehmannii Jur. (Bieder- 
mann et al. 2014), and Zygodon conoideus (Dicks.) Hook. \& Taylor (Seifert 2009a \& 2009b). The records of these species on the German side are sometimes only a few kilometers away from the border to the Czech Republic. Maybe, it is only a matter of time before these species colonize suitable habitat in the Czech Republic.
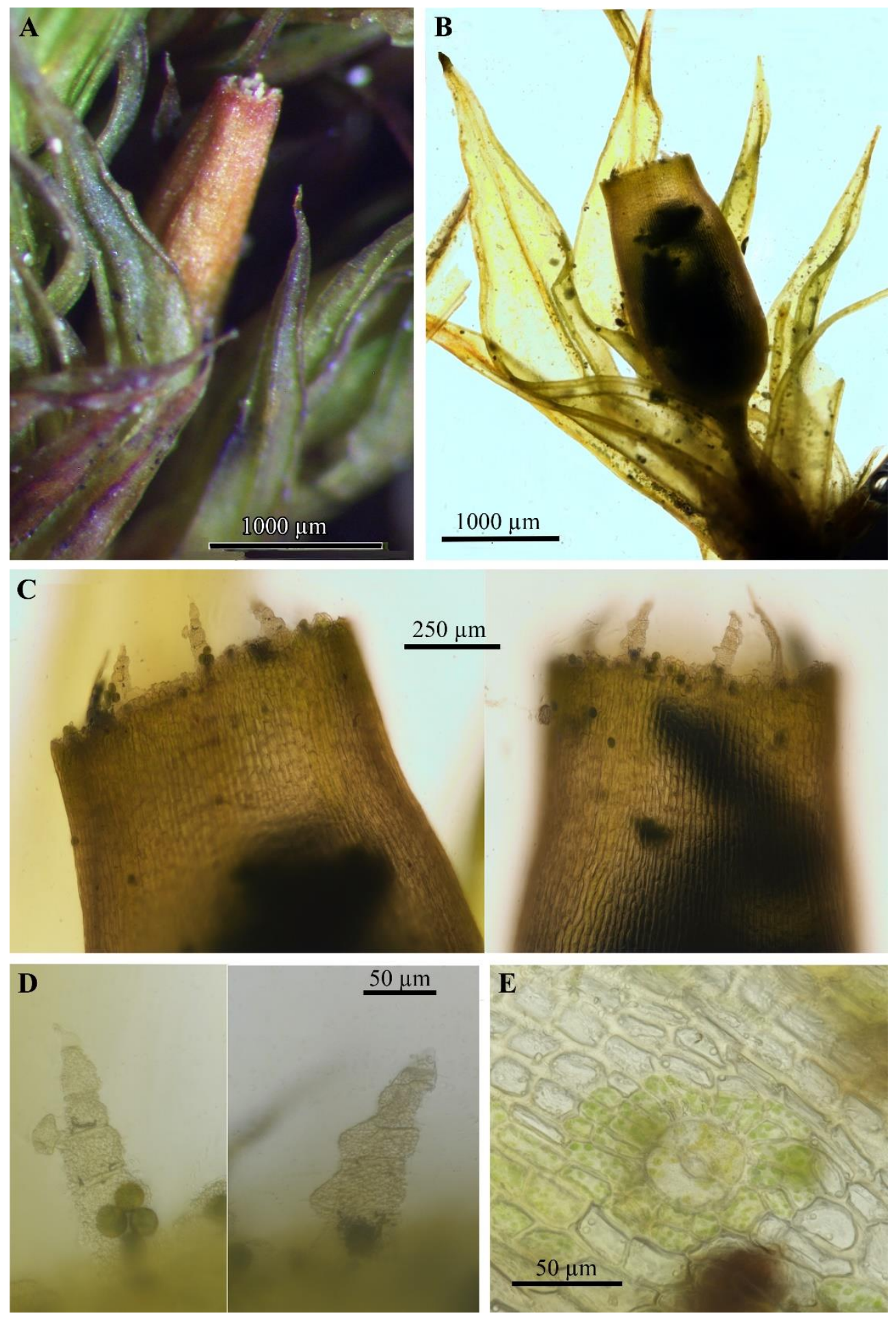

Fig 2: Lewinskya acuminata. A - Detail of apical part of shoot with mature open capsule in dry condition. B - Detail of apical part of shoot with mature open capsule in wet condition. C - Capsule mouth showing a rudimentary or nearly absent exostome and well developed endostome segments. D - Endostome segments. E - Stomata. (All from Müller, DR\#54800). 
Acknowledgment: James R. Shevock kindly checked the English of the paper. The administration of the National Park “České Švýcarsko” I thank for kindly giving permission for investigation of the areas (SNPCS 05157/2017).

\section{References}

Ahrens M. (2004): Zum Vorkommen von Orthotrichum acuminatum H. Philib. und O. consimile Mitt. (Bryopsida, Orthotrichaceae) im Nordschwarzwald. - Carolinea 62: 81-85.

Biedermann S., Müller F. \& Seifert E. (2014): Neu- und Wiederfunde für die Moosflora Sachsens. - Herzogia 27: 215-219.

Blockeel T.L. (2009): A transient occurrence of Orthotrichum acuminatum H. Philib. in Derbyshire, a new British moss. - Journal of Bryology 31(1): 47-49.

BLWG (2019): Orthotrichum acuminatum H. Philib., Gesloten haarmuts. In: NDFF Verspreidingsatlas Mossen. 27 August 2019, https://www.verspreidingsatlas.nl/3276

Eckstein J. (2016): Orthotrichum acuminatum - zweiter Nachweis in Deutschland. - Herzogiella 3: 50-51.

Ellis L.T., Aleffi M., Tacchi M., Alegro A., Alonso M., Asthana A.K., Sahu V., Biasuso A.B., Callaghan D.A., Ezer T., Kara R., Garilleti R., Gil-López M.J., Gwynne-Evans D., Hedderson T.A., Kiebacher T., Larraín J., Long D., Lüth M., Malcolm B., Mamontov Y.S., Newsham K.K., Nobis M., Nowak A., Ochyra R., Pawlikowski P., Plášek V., Č́́hal L., Potemkin A.D., Puche F., Rios D., Gallego M.T., Guerra, J. Sawicki J., Schäfer-Verwimp A., Segarra-Moragues J.G., Šegota V., Sofronova E.V., Ştefănuţ S., Szűcs P., Bidló A., Papp B., Szurdoki E., Tan B.C., Váňa J., Vigalondo B., Draper I., Lara F., Yoon Y.J., Sun B.Y. \& Nishimura N. (2014): New national and regional bryophyte records, 41. - Journal of Bryology 36(4): 306-324.

Lara F., Garilleti R., Medina R. \& Mazimpaka V. (2009): A new key to the genus Orthotrichum in Europe and the Mediterranean region. - Cryptogamie, Bryologie 30(1): 129-142.

Lara F., Garilleti R., Goffinet B., Draper I., Medina R., Vigalondo B. \& Mazimpaka V. (2016): Lewinskya, a new genus to accommodate the phaneroporous and monoicous taxa of Orthotrichum (Bryophyta, Orthotrichaceae). - Cryptogamie, Bryologie 37(4): 361-382.

Marková I. \& Plášek V. (2012): Zygodon dentatus (Limpr.) Kartt., a new moss species in the Bohemian Switzerland National Park (NW Bohemia, Czech Republic). - Časopis Slezského Muzea Opava (A), 61: 251254.

- (2013): Orthotrichum pulchellum Brunt. ex Sm. (Bryophyta) in the Czech Republic. Distribution and ecology.Časopis Slezského Muzea Opava (A), 62: 73-82.

Müller F., Biedermann S., Baumann M. \& Haynold B. (2016): Ergänzungen zur Moosflora Sachsens. Herzogia 29: 643-653.

Müller F., Biedermann S. \& Baumann M. (2019): Bemerkenswerte Moosfunde aus Sachsen und SachsenAnhalt und Neunachweis von Bryum blindii für Deutschland. - Herzogia 32: 239-251.

Philibert H. (1881): Orthotrichum acuminatum. Species nova. - Revue Bryologique 8: 28-31.

Plášek V. \& Marková I. (2007): Orthotrichum pulchellum (Orthotrichaceae, Musci), new to the Czech Republic. - Acta Musei Moraviae 92: 223-228.

Seifert E. (2009a): Epiphytische Moose im Erzgebirge (1997-2008). - Naturpark Erzgebirge Vogtland Spezial 8: $1-62$.

- (2009b): Bemerkenswerte Funde epiphytischer Moose im Erzgebirge im vergangenen Jahrzehnt (2000-2009) praktische und theoretische Probleme der Artbestimmung. - Veröffentlichungen des Museums für Naturkunde Chemnitz 32: 55-92.

Seifert E. \& Müller F. (2017): Orthotrichum shawii im Erzgebirge - Erstfund für Sachsen und Deutschland. Herzogia 30: 343-352.

Van der Pluijm A. (2001): Orthotrichum acuminatum H.Philib., a Mediterranean Moss new to the Netherlands. - Lindbergia 26: 111-114.

Vigalondo B., Lara F., Draper I., Valcarcel V., Garilleti R. \& Mazimpaka V. (2016): Is it really you, Orthotrichum acuminatum? Ascertaining a new case of intercontinental disjunction in mosses. - Botanical Journal of the Linnean Society 180: 30-49.

Author's address: Frank Müller, Institut für Botanik, Technische Universität Dresden, Mommsenstr. 13, 01062 Dresden, Germany.

E-mail: frank.mueller@tu-dresden.de 